\title{
2006-708: THE CSEMS PROGRAM AT PURDUE UNIVERSITY CALUMET
}

Harvey Abramowitz, Purdue University-Calumet

Harvey Abramowitz is Professor of Mechanical Engineering at Purdue University Calumet (PUC)and is the PI for the CSEMS program at PUC.

\section{Roy Hamilton, Purdue University-Calumet}

Roy Hamilton is co PI for the CSEMS program at PUC. He has been the director of the McNair program at PUC for many years. 


\section{The CSEMS Program at Purdue University Calumet}

\section{Overview/History of Program}

The CSEM Scholars Program is administered in conjunction with the Ronald E. McNair PostBaccalaureate Achievement Program (a program designed to prepare first generation college/low-income students and students from underrepresented areas of graduate education for graduate study.) Professor Harvey Abramowitz (Department of Engineering) serves as the CSEM Scholars Program PI with Professor Edward Pierson from the Department of Engineering and Roy Hamilton from the Ronald E. McNair Post-Baccalaureate Achievement Program serving as co-PIs. Organizationally, the McNair Program is part of the Student Services unit of the University. The program is accorded departmental status with the Director as the Department Head. The project director has full responsibility for the program and reports directly to the Vice Chancellor for Student Services and Dean of Students.

\section{Purdue University Calumet Demographics}

Since the Purdue University Calumet student population is drawn from the Calumet Region, the socio-economic and educational characteristics of the region form their background. Hence, the following demographic data for this region was relevant in determining the types of services needed in order to ensure the successful completion of the CSEM Scholars Program.

The Calumet Region in which Purdue University Calumet serves is roughly made up of the urbanized portions of Lake and Porter counties in Indiana, rimming the southern shore of Lake Michigan. One of the most heavily industrialized areas in the United States, the Region is still the biggest steel producing area in the United States.

Historically, cities such as Gary (where a large percentage of the African American student population of Purdue University Calumet resides) evolved through the growth of industries such as U. S. Steel. These communities grew and prospered through the 1960 s as a result of the economic benefits produced by steel manufacturing and processing. However, this period of prosperity suddenly ended in the late 1970s when the area experienced an economic recession. Many smaller steel mills went bankrupt and the larger ones began downsizing their plants. As a result, the area's population lost much of its economic base as thousands of people abruptly found themselves without employment. For example, at its peak, U. S. Steel Corporation (which is located in Gary) employed over twenty-five thousand $(25,000)$ workers. In recent years, this number has fallen to approximately seven thousand $(7,000)$ workers. The population is largely blue-collar working class or low income. Another example was the demise of LTV in East Chicago, IN, which in the summer of 2002 filed for bankruptcy and closed its doors. Not only did over 5,000 persons find themselves without employment, but an additional 4,000 people found either their pension and/or health care affected by the mill's closing. In the past couple of 
years, this trend has started reversing itself due to the reopening of mills, such as LTV by ISG, and the mergers of large steel companies, such as ISG and Bethlehem Steel with Mittal Steel.

There are currently approximately 484,564 people who reside in Lake County, the primary geographic region from which students are drawn for Purdue University Calumet. Over 45\% of this population is congregated in our program's three target student population cities of Gary $(102,746 / 21 \%)$, Hammond (83,048/17\%), and East Chicago $(32,414 / 7 \%)$-- all three bordering on the city of Chicago and South Cook County, Illinois.

Eighty-forty percent (84\%) of Gary's population is African American, while East Chicago's minority population accounts for $87.7 \%$ (51.6\% Hispanic, 36.1\% African American) of that city's total population. In the city of East Chicago, $48 \%$ of the population speaks a language other than English, mostly Spanish. ${ }^{1}$ This is significant in view of findings by a 1980's report of the National Commission on Secondary Education for Hispanics. In its report titled "Make Something Happen," the Commission cited federal statistics that show:

1) $40 \%$ of all Hispanics who leave school do so before entering $10^{\text {th }}$ grade.

2) $45 \%$ of Mexican American and Puerto Rican students never finish high school.

3) Almost $25 \%$ of all Hispanics enter high school over age.

4) $76 \%$ scored in the bottom half of standardized achievement tests.

Over a decade later, the Educational Testing Service, (May 2002) reports still alarming data. ETS reports that only four (4\%) of Hispanic twelfth graders scored at or above the Proficient level on the National Assessment of Educational Progress (NAEP) mathematics assessment. This is of great concern considering that in order to pursue careers and study in areas of national need such as mathematics and the sciences, students need to possess proficiency in mathematics. ${ }^{2}$

\section{Profile of Purdue University Calumet Students}

Of the 8,283 undergraduate students enrolled during the 2004 Fall Semester (which is typical of the pool from which eligible applicants are taken):

- 4,680 (56.5\%) attended full-time, while 3,603 (43.5\%) attended part-time

- 5,582 (67.4\%) were Caucasian

- 1,251 (15.1\%) were African American

- $1,234(14.9 \%)$ were Hispanic

- 115 (1.4\%) were Asian Pacific Island

- $25(0.3 \%)$ were American Indian or Native Alaskan

- 3,644 (44\%) were males

- $4,639(56 \%)$ were females

- 25 years was the average age of males

- 27 years was the average age of females 
- $6,212(75 \%)$ were first generation

- 124 (1.5\%) were Students with Disabilities

\section{Philosophy of Administering and Implementing NSF Grant}

As stated earlier, a large percentage of the Purdue University Calumet student body is firstgeneration college. The institution has over a thirty year record of providing services to students who are first-generation college and from underrepresented groups in graduate education through the federal TRIO Programs. The effectiveness of the TRIO Programs, in part, is the result of meaningful collaboration among departments found in Academic Affairs and Student Services. Thus, the CSEM Scholars Program was designed in some ways to mirror the effective Academic Affairs/Student Services collaboration - the development of a network of departments, programs, faculty, and staff that advance educational opportunity and access. In short, Student Service departments provide activities and supportive services that support the instruction and scholarship of Academic Affairs departments.

The department of Engineering and the Ronald E. McNair Post-Baccalaureate Achievement Program are the primary collaborators for the CSEM Program at Purdue University Calumet. Each area works in tandem to provide a holistic approach to student success and learning. It is well understood that because of the socio-economic background of the Purdue University Calumet student, it was important that the CSEM Scholar Program provide services that not only support the instructional life of students, but services designed to address barriers that might impede student success - the achievement of a baccalaureate and/or associate degree. To this end, CSEM Scholars were assessed to determine academic, counseling, and financial needs; and an individualized service plan was developed to determine goals for each student that allowed for the development of a plan of study that increased the likelihood that each scholar would maximize his/her potential for pursing graduate study and employment after undergraduate study. Each CSEM Scholar was paired with a faculty in his/her major discipline who would serve as his/her mentor. The CSEM Scholar Program directors, with the assistance of CSEM faculty mentors, were able to provide and/or refer scholars to services in the departments and services listed in Table I.

\section{Selection Process and Continued Program Participation}

In order to select students for participation for the program, the CSEM Scholars selection committee was formed. This selection committee was comprised of CSEM discipline faculty members and staff from Student Services. The selection committee used indicators for academic merit and other indicators of likely academic and professional success as their selection criteria. Students applying for the CSEM Scholars Program did so in the following categories: Freshmen Level Scholars and Junior Level Scholars. The following criteria and point value were used to evaluate Freshman Level Scholars: high school grade point average - 10 points; high school rank - 10 points; SAT score with special consideration for the math score -10 points; letters of recommendation -35 points; and personal statement 35 - points. The following criteria and point value were used to evaluate Junior Level Scholars: college grade point average - 30 points; letters of recommendation - 35 points; and personal statement 35 - points. 
Table I: Departments, Programs, and Individuals Who Provide Service

\begin{tabular}{|c|c|}
\hline Department & Services \\
\hline CSEM Scholars Program & $\begin{array}{l}\text { Funding for conference and graduate school participation, } \\
\text { academic advising }\end{array}$ \\
\hline $\begin{array}{l}\text { Undergraduate Research } \\
\text { Program }\end{array}$ & Research opportunities with Purdue Calumet faculty \\
\hline $\begin{array}{l}\text { Student Support Services } \\
\text { Program }\end{array}$ & $\begin{array}{l}\text { Individualized tutoring, personal counseling, pre-advising, } \\
\text { graduate school visitations, financial aid counseling }\end{array}$ \\
\hline $\begin{array}{l}\text { Ronald E. McNair Post- } \\
\text { Baccalaureate } \\
\text { Achievement Program }\end{array}$ & $\begin{array}{l}\text { Individualized tutoring, personal and career counseling, assistance } \\
\text { with graduate school application process, graduate school } \\
\text { visitations, summer research internships, graduate school seminars }\end{array}$ \\
\hline Skills Assessment Center & Group tutoring, supplemental instruction \\
\hline $\begin{array}{l}\text { Center for Career and } \\
\text { Leadership Development } \\
\text { (Career Services) }\end{array}$ & $\begin{array}{l}\text { Assistance with internships, resume development, interview skills, } \\
\text { development of cover letters }\end{array}$ \\
\hline $\begin{array}{l}\text { Louis Stokes Alliance for } \\
\text { Minority Participation }\end{array}$ & Research internships \\
\hline Counseling Center & Career and personal counseling, wellness seminars \\
\hline $\begin{array}{l}\text { Coordinator of Student } \\
\text { With Disabilities }\end{array}$ & Accommodations for students with documented disabilities \\
\hline $\begin{array}{l}\text { Departmental Faculty } \\
\text { Mentors }\end{array}$ & $\begin{array}{l}\text { Serve as advocates for the CSEM Scholar in the major department } \\
\text { in terms of advising, problem resolution and report to the CSEM } \\
\text { staff any needs/concerns regarding the scholar or the scholar's } \\
\text { academic progress }\end{array}$ \\
\hline TRIO Learning Center & $\begin{array}{l}\text { Access to networked computers, fax machine, copier, and video } \\
\text { conference room }\end{array}$ \\
\hline
\end{tabular}

Upon selection into the program, each scholar was required to sign a program participation agreement, complete a program survey, and an individualized service plan. In order to maintain participation in the program, each scholar is to earn a grade point average of 3.0 each semester; enroll in at least twelve (12) credit hours of coursework; and must be enrolled in a CSEM discipline. For those scholars whose semester grade point average falls below 3.0, scholars are required to meet with one of the CSEM directors to discuss not meeting the academic semester expectation. In most cases, these scholars are placed on probation with the program and are required to receive academic support and tutoring from the Student Support Service Program and/or Skills Assessment and Tutoring. After the semester of probation, the scholar's academic record is reviewed for continued participation. Finally, in order to provide academic intervention, progress report forms are mailed to each scholar's instructors. These forms allow the CSEM directors to gain early insight into the scholars' level of performance in each class. Information from this form is shared with each scholar. Particular effort is made to share this information with scholars whose academic performance is not good. 


\section{Results}

Number of Scholarships

The students applying for the scholarships consisted of new students (freshman level) and continuing students. There have been three rounds of competitions for acceptance into the program. These took place prior to the Fall 2001, Fall 2002 and Spring 2006 semesters. Combined, these competitions yielded 69 scholars from an application pool of 93 students, giving an acceptance rate of $74 \%$.

\section{Demographics of Scholars}

Table II gives the ethnic make up of the CSEM Scholars Program since its funding in 2001. The proportion of students chosen for participation in CSEM approximates or exceeds the proportion of students in terms of ethnicity for the total Purdue University Calumet undergraduate student population.

Further breakdown of scholars by ethnicity and gender is found in Table III. Females represent 43 percent of all Scholars chosen.

The students that have been awarded scholarships are majoring in a variety of technical fields (Table IV). The departments that have one or more CSEM Scholars are: Engineering (both EE and ME), Mathematics, Electrical Engineering Technology, Construction Management and Engineering Technology, Mechanical, Manufacturing Technology and Supervision, and Computer Information Technology.

\section{Progress of Students}

Table V lists the Scholars' academic performance, in terms of semester GPA and cumulative GPA after the given semester. A semester GPA of 3.0 is the goal for every student in the program. For all semesters that the program has run, the percentage of Scholars reaching this goal has ranged from 65 to $90 \%$. If the percentages of GPA over 2.8 are considered, then the percentages range from 71 to 90 . Looking at cumulative GPAs, the ranges were 60 to $88 \%$ for at least a 3.0 average, and 72 to 95 for a minimum of 2.8 .

The ultimate goals of the program are either completion of the first 2 years (obtaining an Associates degree where applicable), or completion of all requirements for a Bachelors degree. Given these goals, the program to date has been a success (Table VI), producing 30 Bachelor degrees and 14 Associate degrees. For the total of 69 Scholars, 59\% have received at least one degree. Three students have received two degrees. 
TABLE II: CSEM SCHOLARS BY ETHNICITY

\begin{tabular}{|l|c|c|}
\hline Ethnicity & Number & Percentage \\
\hline Caucasian & 44 & 64 \\
\hline African American & 14 & 20 \\
\hline Hispanic & 10 & 14 \\
\hline Asian/Pacific Islander & 1 & 2 \\
\hline TOTAL & $\mathbf{6 9}$ & $\mathbf{1 0 0}$ \\
\hline
\end{tabular}

TABLE III: CSEM SCHOLARS BY GENDER BY ETHNICITY

\begin{tabular}{|l|l|l|l|}
\hline Gender \& & Number & Percentage & Percentage \\
\hline Ethnicity & & Total & Gender \\
\hline Male & 39 & 57 & 100 \\
\hline Caucasian & 27 & 39 & 69 \\
\hline African American & 6 & 9 & 15 \\
\hline Hispanic & 5 & 7 & 13 \\
\hline Asian/Pacific Islander & 1 & 2 & 3 \\
\hline Female & 30 & 43 & 100 \\
\hline Caucasian & 17 & 25 & 57 \\
\hline African American & 8 & 12 & 27 \\
\hline Hispanic & 5 & 7 & 16 \\
\hline Asian/Pacific Islander & 0 & 0 & 0 \\
\hline
\end{tabular}

\section{TABLE IV: CSEM SCHOLARS BY DISCIPLINE}

\begin{tabular}{|l|c|c|}
\hline Discipline & Number & Percentage \\
\hline & & \\
\hline Engineering (ME \& EE) & 27 & 39 \\
\hline Mathematics & 6 & 9 \\
\hline Construction Management \& Engineering Technologies & 5 & 7 \\
\hline Electrical and Computer Engineering Technologies & 5 & 7 \\
\hline Manufacturing Engineering Technology & 8 & 12 \\
\hline Computer Information Technology & 18 & 26 \\
\hline TOTAL & $\mathbf{6 9}$ & $\mathbf{1 0 0}$ \\
\hline
\end{tabular}


TABle V: CSEM Scholars ACADEMiC PERformanCE - GPA

\begin{tabular}{|l|l|l|l|l|l|l|l|l|}
\hline & $\begin{array}{l}\text { Fall } \\
\mathbf{2 0 0 1}\end{array}$ & $\begin{array}{l}\text { Spring } \\
\mathbf{2 0 0 2}\end{array}$ & $\begin{array}{l}\text { Fall } \\
\mathbf{2 0 0 2}\end{array}$ & $\begin{array}{l}\text { Spring } \\
\mathbf{2 0 0 3}\end{array}$ & $\begin{array}{l}\text { Fall } \\
\mathbf{2 0 0 3}\end{array}$ & $\begin{array}{l}\text { Spring } \\
\mathbf{2 0 0 4}\end{array}$ & $\begin{array}{l}\text { Fall } \\
\mathbf{2 0 0 4}\end{array}$ & $\begin{array}{l}\text { Spring } \\
\mathbf{2 0 0 5}\end{array}$ \\
\hline Number of Scholars & 19 & 20 & 53 & 52 & 48 & 43 & 29 & 24 \\
\hline \% Semester GPA $>\mathbf{2 . 8 0}$ & 79 & 90 & 70 & 71 & 83 & 86 & 90 & 83 \\
\hline \% Semester GPA $>\mathbf{3 . 0 0}$ & 68 & 75 & 68 & 65 & 79 & 79 & 83 & 75 \\
\hline \% Cumulative GPA $>\mathbf{2 . 8 0}$ & 89 & 95 & 74 & 72 & 81 & 79 & 90 & 92 \\
\hline \% Cumulative GPA $>\mathbf{3 . 0 0}$ & 74 & 75 & 60 & 67 & 75 & 74 & 83 & 88 \\
\hline
\end{tabular}

TABle VI: CSEM SChOlaRS DegReE ObTAINMENT

\begin{tabular}{|c|l|l|l|l|l|l|l|}
\cline { 2 - 8 } \multicolumn{1}{c|}{} & Year & $\mathbf{2 0 0 1 - 2 0 0 2}$ & $\mathbf{2 0 0 2 - 2 0 0 3}$ & $\mathbf{2 0 0 3 - 2 0 0 4}$ & $\mathbf{2 0 0 4 - 2 0 0 5}$ & $\mathbf{2 0 0 5 - 2 0 0 6}$ & Total \\
\hline Degree & & & & & & & \\
\hline Associate (\#) & & 2 & 4 & 5 & 2 & 1 & 14 \\
\hline Bachelor (\#) & 0 & 3 & 11 & 13 & 3 & 30 \\
\hline TOTAL & & $\mathbf{2}$ & $\mathbf{7}$ & $\mathbf{1 6}$ & $\mathbf{1 5}$ & $\mathbf{4}$ & $\mathbf{4 4}$ \\
\hline
\end{tabular}

Note: Of the sixty-nine students chosen as CSEM Program Scholars, 59\% have received the bachelor and/or associate degree.

TAble VII: Post Graduate ACtivity of CSEM Scholars

\begin{tabular}{|l|c|c|}
\hline Post Graduate Activity & Number & Percentage \\
\hline \hline Graduate School & 1 & 3 \\
\hline Employment & 15 & 47 \\
\hline Graduate School and Employment & 7 & 22 \\
\hline Enrolled in bachelor's program after receiving associate's degree & 4 & 13 \\
\hline Other & 5 & 16 \\
\hline TOTAL & $\mathbf{3 2}$ & $\mathbf{1 0 0}$ \\
\hline
\end{tabular}


Table VII reflects the post graduate activity of the Purdue University Calumet CSEM Scholars. The number of Scholars who responded to a post graduate activity survey was less than the number that received degrees. Included in the other category are students who are out of the work force for personal reasons or are currently seeking employment. Scholars are or have been employed by corporations such as Caterpillar, Proctor and Gamble, Lockheed, Ford Motor Company, Crane Naval, and Keslin Engineering (Valparaiso, IN). In addition, Scholars have enrolled in graduate engineering and business programs at Purdue University Calumet, Purdue University (West Lafayette), and Stanford University.

\section{Implications for the future}

\section{Funds for grant administration}

Unfortunately, the National Science Foundation CSEM Program grant does not allow for the charging of personnel costs to the grant, such as clerical and administrative support. This places an extra work load on the PIs, since no release time has been allocated to them for administrating the program. We suggest that some funds be available in future grants in order to provide the administrators sufficient time to effectively run the programs.

\section{Mathematics Scores}

Out of the sixty nine students chosen for participation in the program, fourteen scholars have been dismissed- two students changed their major to a non-CSEM discipline, seven for poor academic performance, four withdrew from Purdue University Calumet (two due to illness), and one decided to take less than a full load. In the cases where students changed their majors it was due to lack of appropriate mathematical skills to handle the curricula of the engineering, technology, and mathematics majors. We have found on the occasions where students have received semester grade point averages less than 3.00, they received a low or failing grade in a mathematics course. This is a challenge faced not only by CSEM Scholars, but students university-wide. In order to meet this challenge university-wide, mathematics courses with high rates of students withdrawing and receiving failing grades have been re-designed to include supplemental instruction (SI).

The first semester of full implementation of the SI program at Purdue University Calumet occurred in the Fall of 2003. By Spring 2005, twenty one different disciplines were using SI. Consistent with national averages, PUC has experienced a final grade outcome that shows SI students received a half letter grade higher than do non-SI participants in the same course. Courses for Fall 2004 and Spring 2005 where SI participants received significantly higher (than normal) grades than non-SI students were chemistry, English, mathematics, engineering, management, and foreign languages. ${ }^{3}$ 


\section{References}

1. U. S. Department of Commerce, Bureau of the Census, Census 2000: Public Law 94-171, Hispanic Origin, Persons Over 18, Housing Units, updates prepared by Northwest Indiana Regional Planning Commission, 2001.

2. Barton, Paul E., Policy Information Report: Meeting the Need for Scientists, Engineers, and Educated Citizenry in a Technological Society (Educational Testing Service, May 2002), p. 16.

3. Reason, J., Supplemental Instruction Program Quality Assessment Fall 2003- Spring 2005, Purdue University Calumet, February 2006. 